\title{
Author Correction: B-cell depletion induces a shift in self antigen specific B-cell repertoire and cytokine pattern in patients with bullous pemphigoid
}

Nicolas Berkani, Pascal Joly, Marie-Laure Golinski, Natacha Colliou, Annick Lim, Anis Larbi Gaetan Riou, Frederique Caillot, Philippe Bernard, Christophe Bedane, Emmanuel Delaporte, Guillaume Chaby, Anne Dompmartin, Michael Hertl, Sebastien Calbo \& Philippe Musette

Correction to: Scientific Reports https://doi.org/10.1038/s41598-019-40203-7, published online 05 March 2019

The original version of this Article contained errors in the names of the authors Nicolas Berkani, Pascal Joly, Marie-Laure Golinski, Natacha Colliou, Annick Lim, Anis Larbi, Gaetan Riou, Frederique Caillot, Philippe Bernard, Christophe Bedane, Emmanuel Delaporte, Guillaume Chaby, Anne Dompmartin, Michael Hertl, Sebastien Calbo \& Philippe Musette which were incorrectly given as Berkani Nicolas, Joly Pascal, Golinski Marie-Laure, Colliou Natacha, Lim Annick, Larbi Anis, Riou Gaetan, Caillot Frederique, Bernard Philippe, Bedane Christophe, Delaporte Emmanuel, Chaby Guillaume, Dompmartin Anne, Hertl Michael, Calbo Sebastien \& Musette Philippe respectively.

As a result, the original version of this Article contained errors in the Author Contributions section.

"B.N., J.P., C.S. and M.P. wrote the paper. B.N., G.M.L., C.N., C.F., L.i.A., L.a.A., R.G., H.M., C.S. and P.M. acquired and analyzed the data. B.P., B.C., D.E., C.G. and D.A. included patients."

now reads:

"N.B, P.J., S.C. and P.M. wrote the paper. N.B., M.L.G., N.C., F.C., A.L.i.., A.L.a., G.R., M.H., S.C. and P.M. acquired and analyzed the data. P.B., C.B., E.D., G.C. and A.D. included patients."

Additionally, the Supplementary Information File 'Clean Supple Mat' was a duplication of 'Supplementary Dataset 1'

These errors have now been corrected in the PDF and HTML versions of the Article, and in the Supplementary Dataset file.

\begin{abstract}
(c) (i) Open Access This article is licensed under a Creative Commons Attribution 4.0 International sy License, which permits use, sharing, adaptation, distribution and reproduction in any medium or format, as long as you give appropriate credit to the original author(s) and the source, provide a link to the Creative Commons license, and indicate if changes were made. The images or other third party material in this article are included in the article's Creative Commons license, unless indicated otherwise in a credit line to the material. If material is not included in the article's Creative Commons license and your intended use is not permitted by statutory regulation or exceeds the permitted use, you will need to obtain permission directly from the copyright holder. To view a copy of this license, visit http://creativecommons.org/licenses/by/4.0/.
\end{abstract}

(c) The Author(s) 2019 